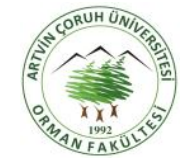

\title{
Kırklareli Kavaklımeşe Korusu Tabiat Parkının rekreasyon potansiyelinin belirlenmesi
}

\section{Determination of recreation potential at The Kırklareli Kavaklımeşe Korusu Natural Park}

\author{
Fürüzan ASLAN ${ }^{1}(\mathbb{D})$, Oğuz ATEŞ ${ }^{1}(\mathbb{D})$, Nehar BÜYÜKBAYRAKTAR ${ }^{1}{ }^{(D)}$ Engin KABATAŞ$^{1}$
}

${ }^{1}$ Kırklareli Üniversitesi, Mimarlık Fakültesi, Peyzaj Mimarlığı Bölümü, Kırklareli, TÜRKiYE

\section{Eser Bilgisi / Article Info}

Araştırma makalesi / Research article

DOI: 10.17474/artvinofd.946339

Sorumlu yazar / Corresponding author

Oğuz ATEŞ

e-mail: oguzates@klu.edu.tr

Geliş tarihi / Received

01.06.2021

Düzeltme tarihi / Received in revised form

04.11.2021

Kabul Tarihi / Accepted

05.11.2021

Elektronik erişim / Online available

18.11.2021

\section{Anahtar kelimeler:}

Rekreasyon potansiyeli

Gülez yöntemi

Kırklareli

Kavaklımeşe korusu

\section{Keywords:}

Recreation potential

Gülez method

Kırklareli

Kavaklımeşe korusu

\begin{abstract}
Özet
Bu araştırmada Kırklareli ilinde bulunan Kırklareli Kavaklımeşe Korusu Tabiat Parkı'nın rekreasyon potansiyelinin belirlenmesi amaçlanmıştır. Rekreasyon potansiyelinin belirlenebilmesi için ülkemizdeki pek çok çalışmada kullanıımış Gülez yönteminden yararlanılmıştır. Çalışma alanına 2020 yılı Eylül, 2021 yılı Mayıs ve Haziran aylarında 4 hafta içi ve 5 hafta sonu olmak üzere toplamda 9 kere gidilmiş ve yerinde gözlemler yapılarak rekreasyon potansiyeli belirlenmeye çalışılmıştır. Araştırma sonucunda Kırklareli Kavaklımeşe Korusu Tabiat Parkı'nın rekreasyon potansiyelinin \%59 (orta düzey) olduğu ortaya konmuştur. Alanda bulunan yapı ve tesisler iyileştirilerek, rekreatif kolaylıklar arttırılarak, olumsuz etmenler giderilerek Kırklareli Kavaklımeşe Korusu Tabiat Parkı'nın rekreasyon potansiyelinin arttırılabileceği sonucuna ulaşılmıştır.
\end{abstract}

\begin{abstract}
In this study, it was aimed to determine the recreation potential of Kırklareli Kavaklımeşe Korusu Nature Park in Kırklareli province. In order to determine the recreational potential, the Gülez method, which has been used in many studies in Turkey, has been used. The study area was visited 9 times in total, 4 weekdays and 5 weekends in September at 2020, May and June at 2021, and the recreation potential was tried to be determined by making on-site observations. As a result of the research, it was concluded that the recreation potential of Kırklareli Kavaklımeşe Korusu Nature Park is 59\% (medium level). The recreational potential of the Kırklareli Kavaklımeşe Korusu Nature Park can be increased by improving the buildings and facilities and areas, increasing the recreational facilities and eliminating the negative factors.
\end{abstract}

\section{GiRiş}

19.yy sonrası ortaya çıkan teknolojik gelişmeler, çalışma şartlarında meydana gelen iyileşmeler ve makineleşme ile insanların boş zamanlarında artış görülmüştür. Illk etapta tembellik ve savurganlık olarak tanımlanan boş zaman kavramı, sonradan kişinin ruhsal, zihinsel ve bedensel gelişimini destekleyen temel bir gereksinim olarak ifade edilmiştir. Ilerleyen zamanlarda ise boş zaman kavramı yerine rekreasyon terimi kullanılmaya başlanmıştır (Çidam 2007, Çakır ve Çakır 2012).

Latince "recreatio" kelimesinden gelen, yenilenme, yeniden yapılanma ve yeniden yaratılma anlamındaki rekreasyon, kişilerin boş zamanlarını değerlendirdiği ve gönüllü olarak seçtiği etkinlikleri kapsamaktadır (Serarslan ve Bakır 1988). Rekreasyon, insanların, günlük hayatta sürekli karşılaştıkları stresi yok etmek, monoton çalışma düzeninin ardından yorulan bedenlerini yenilemek, enerji kazanmak ve verimli çalışma zamanına hazırlanmak için yaptıkları, hoşlandığı bir işle uğraşma faaliyetidir (Aran 1967, Öztürk 2005). Bir başka ifade ile rekreasyon; insanların gönüllü olarak katıldıkları, çalışma, görev ve ödev vb. zorunlu olarak yerine getirmesi gerektiği etkinlikler sonrasında kalan boş zamanlarında dinlenmek, eğlenmek ve yenilenmek maksatlı etkinlik ya da deneyimleri ifade etmektedir (Kraus 1977, Surat 2017).

Rekreasyonel aktiviteler ise, rekreasyon amacıyla yapılan her türlü eğlenme, dinlenme ve rahatlama faaliyetleridir (Kılıçaslan 2008). Günlük yapılması gereken zorunlu işler dışındaki, sağlık üzerinde olumlu etkileri olan, zevk alınan, bireysel, grup, aktif, pasif olarak yapılabilen aktivitelerdir (Nowaczek 2003). Rekreasyonel aktivitelerin gerçekleştirildiği mekanlar olarak tanımlanan rekreasyon alanları, bu amaçlar doğrultusunda tasarlanmış olabileceği gibi (parklar, çocuk oyun alanları vb.), kendi içerisinde var olan nitelikleriyle de (Ormanlar, kıyılar vb.) rekreasyonel aktivitelerin gerçekleştirilebildiği mekanlar olabilirler (Uzun 2005). 
Bir yerin topografik yapısı, flora ve faunası, su kaynaklarına yakınlığı, doğal oluşumların varlığı ve iklimsel özellikleri, rekreasyonel alanlardaki çekiciliği sağlayan başlıca unsurlardandır (Surat 2017). Bunların yanı sıra eğitim, sağlık ve dinlenme imkanları, spor faaliyetleri sunması, haberleşme ve ulaşım kolaylıkları, alt ve üst yapı varlığı vb. nedenler de rekreasyonel çekiciliği arttırmaktadır (Yılmaz 2004).

Günümüzde rekreasyonel talep ve çeşitlilik konusunda önemli değişimlere ve gelişmelere yol açan en önemli unsur, 19.yy sonrası sosyal, ekonomik, kültürel ve teknolojik gelişmelerle birlikte, özellikle kentleşme ile ortaya çıkan olumlu ve olumsuz sonuçlardır. Kent içindeki açık ve yeşil alanların nitelik ve nicelik olarak yetersizliği, kentte yaşayanları kente yakın, rekreasyon potansiyeli yüksek, flora ve fauna açısından zengin, doğal peyzaj çeşitliliği fazla olan alanlara çekmektedir (Putz ve ark. 2001, Masozera ve Alavalapati 2004, Surat 2017).

Bu nedenlerle tüm bu rekreasyon alanlarının rekreasyon potansiyelinin belirlenmesi; sorunların tespit edilmesi, olumsuzlukların giderilmesi, taşıma kapasitesinin aşılmaması ve planlama ve tasarım aşamalarının daha sağlıklı yürütülebilmesi için oldukça önemlidir. Bu bağlamda rekreasyon potansiyelinin belirlenmesine yönelik literatürde pek çok araştırma bulunmaktadır. Bu araştırmalara; Clawson (1959)'un açık hava rekreasyonuna olan talebi ve değeri ölçme yöntemi, Knetsch (1963)'in açık hava rekreasyon talep ve faydalarını tespit ettiği yöntemi, Daiute (1966)'un dış mekan rekreasyon taleplerinin belirlenmesi yöntemi, Lier (1972)'in yer, kapasite ve yerleşim sorunlarına odaklandığı yöntemi, Clark ve Stankey (1979)'in bir rekreasyon alanına değer veren fiziksel, biyolojik, sosyal ve yönetimsel koşulların birleşimi olan Rekreasyon Fırsatı Spektrumu (Recreation Opportunity Spectrum (ROS) yöntemi ve Gülez (1990) tarafından orman içi rekreasyon potansiyelinin belirlenmesine ilişkin yöntemi örnek verilebilir.

Rekrasyon potansiyeli belirlenirken ülkemizdeki pek çok çalışmada kullanılan (Yılmaz vd. 2009, Korkut ve Şimşek 2009, Birici vd. 2016, Çelik vd. 2016, Çelik ve Çalışkan 2017, Sü Eröz ve Aslan 2017, Atabeyoğlu vd. 2017, Surat 2017, Yeşil ve Hacıoğlu 2018, Gül ve Yılmaz 2019, Özçalık ve Kumru 2019, Bozkurt 2019, Pekünlü vd. 2020, Çetinkale Demirkan ve Sandal Erzurumlu 2020, Tozkoparan vd. 2020, Çavuş ve Aker 2021, Tülek 2021) Gülez yönteminden yararlanılmıştır. Gülez yöntemi peyzaj değeri, iklim değeri, ulaşılabilirlik, rekreatif kolaylıklar ve olumsuz etmenler başıkları altında puanlamalar yaparak alanın rekreasyon potansiyelini ortaya koymaktadır.

Bu çalışmada, Kırklareli ilinde bulunan Kavaklımeşe Korusu Tabiat Parkı özelinde bir rekreasyonel potansiyel değerlendirme çalışması yapılmıştır. Parkın rekreasyonel potansiyelinin belirlenmesinde Gülez yönteminden yararlanılmış ve aynı yöntemle yapılan çalışmalar ile Kavaklımeşe Korusu Tabiat Parkı karşılaştırılmıştır. Rekreasyonel potansiyelin belirlenmesi sonrasında alandaki sorun ve potansiyellere yönelik değerlendirmelerde bulunulmuş ve parkın rekreasyonel potansiyelinin artırılmasına yönelik çözüm ve öneriler sunulmuştur.

\section{MATERYAL ve YÖNTEM}

\section{Materyal}

Çalışmanın ana materyalini Kavaklımeşe Korusu Tabiat Parkı oluşturmaktadır (Şekil 1). 11.07.2011 tarihinde tabiat parkı ilan edilen alan, 35.55 Ha büyüklüğündedir. Günübirlik kullanım özelliklerine sahip olan park; Kırklareli-Babaeski yolu üzerinde, Kırklareli iline $12 \mathrm{~km}$ uzaklıkta, Kavaklı Beldesinde yer almaktadır.

Çalışma alanı üst miyosen yaşında, (m3pl(a)) karasal kırıntılılar jeolojik formasyonuna sahiptir. Derinliği 5 ila $150 \mathrm{~m}$ arasında değişmektedir. En yakın diri fay hattı Marmara denizinden geçen Kuzey Anadolu Fayıdır. Çalışma alanının yakın çevresinde heyelan veya taşkın alanı bulunmamaktadır (MTA, 2021).

Çalışma alanının toprak yapısı ise Kireçsiz Kahverengi Topraklardan oluşmaktadır. Arazi kullanım kabiliyet sınıfı 2. Sınıf olarak belirlenmiştir. Rakım değerlerinin ise $170-$ $175 \mathrm{~m}$ arasında değiştiği görülmektedir. Alanın ağırlıklı olarak Güney - Güneybatı - Güneydoğu bakarlı olduğu tespit edilmiştir. Alanın hakim eğimi ise $\% 0-2$ düz ve düze yakın eğim sınıfındadır.

Kırklareli ilinde iklim yörelere göre farklılaşmaktadır. Denizden uzak kısımlarda karasal iklim görülürken, Yıldız dağlarının kuzeye bakan kısımlarında Karadeniz iklimi görülmektedir. Çalışma alanında karasal iklim tipi hüküm sürmektedir. Bu iklim tipine bağlı olarak yazları sıcak ve kurak, kışları soğuk ve zaman zaman kar yağışlı geçmektedir (Kırklareli il Kültür ve Turizm Müdürlüğü, 2021).

Kırklareli Meteoroloji İstasyonundan alınan 1980 - 2019 yılları arası ortalama verilere göre yıllık ortalama küresel

322 /F. Aslan, O. Ateş, N. Büyükbayraktar, E. Kabataş / AÇÜ Orman Fak Derg 22(2):321-330 (2021) 
güneş radyasyonu $342.5 \mathrm{cal} / \mathrm{cm}^{2}$, yıllık ortalama yağış $568.7 \mathrm{~mm}$, yıllık ortalama sıcaklık $13.5^{\circ}$, yıllık ortalama nispi nem \%69.2 ve yıllık ortalama rüzgar hızı $1.5 \mathrm{~m} / \mathrm{sn}$ olarak tespit edilmiştir (MGM, 2020).

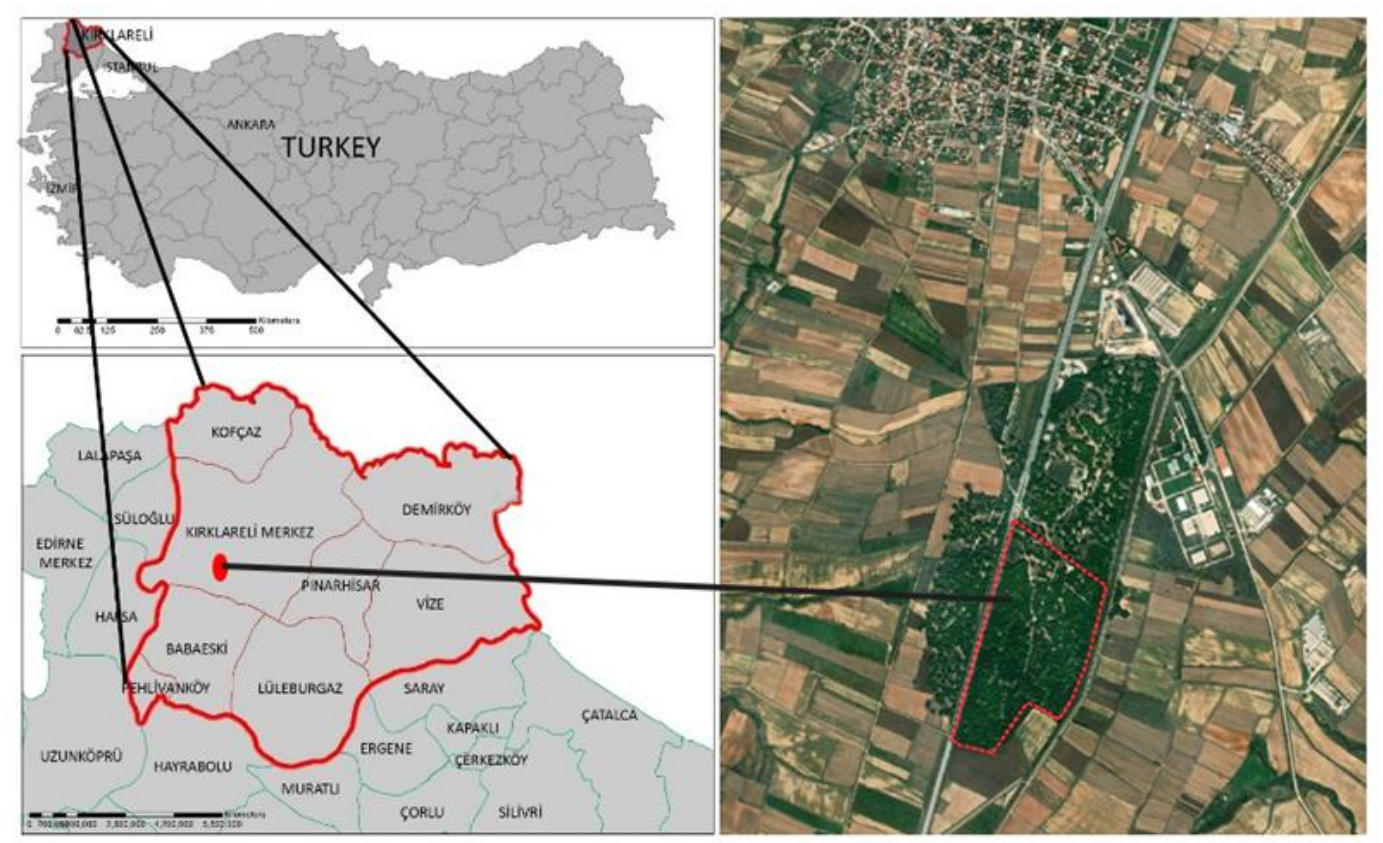

Şekil 1. Çalışma alanının konumu (OGM 2021).

\section{Yöntem}

Bu çalışmada Gülez (1990) tarafından geliştirilen "Açık hava ve ormanlık alanların rekreasyon potansiyelinin belirlenmesi" yönteminden yararlanılmıştır.

Gülez (1990) tarafından ülkemiz koşullarına uygun olarak geliştirilen ve orman içi açık hava rekreasyon potansiyelinin hesaplanmasına olanak sağlayan yöntem arazinin belirli parametreler doğrultusunda analiz edilmesi ve puanlanmasından oluşmaktadır. Yöntemde kullanılan parametreler ve puanlandırma sistemi Çizelge $1^{\prime}$ de ifade edilmiştir. Çizelgede yer alan parametreler, çalışma alanı ile ilgili elde edilen sayısal veri ve gözlemler doğrultusunda ayrı ayrı puanlanmakta ve tüm puanlar aşağıda ifade edilen formülle hesaplanarak alanın rekreasyonel değerine ulaşılmaktadır.

$$
R P(\%)=P+i+U+R K+O S E
$$

(P) Peyzaj Değeri: Rekreasyon potansiyelinin değerlendirilirken, peyzaj potansiyeli en önemli özelliktir. Bu yüzden ağırlığı \%35'dir.

(i)iklim Değeri: Sıcaklık, Yağış, güneşlenme ve rüzgar parametreleri toplanarak elde edilen iklim değeri, \%25 ağırlığa sahiptir.
(U)Ulaşılabilirlik: Bir rekreasyon alanına ne kadar rahat ulaşılabiliyorsa, o alanın rekreasyona uygunluğu o kadar artmaktadır. Ulaşılabilirlik ögesi \%20 ağırlıkla hesaplamaya katılmaktadır.

(RK)Rekreatif Kolaylık: Bir rekreasyon alanında yer alan tüm rekreatif kolaylıklar (wc, çeşme, piknik masası vb.), rekreasyonel potansiyel açısından önem taşımaktadır. Rekreasyon potansiyeli hesaplamasında \%20 ağırlıkla değerlendirilmektedir.

(OSE) Olumsuz Etkenler: Rekreasyonel potansiyel saptanırken, olumsuz durumlar da göz önüne alınmalıdır. Gülez yöntemine göre bu ögenin alabileceği maksimum puan $-10^{\prime}$ dur.

Çalışma alanına 2020 yılı Eylül, 2021 yılı Mayıs ve Haziran aylarında 4 hafta içi ve 5 hafta sonu olmak üzere toplamda 9 ziyaret düzenlenmiştir. Yapılan arazi gözlemleri, analiz çalışmaları, alanla ilgili literatür taraması ve park görevlileriyle yapılan kısa görüşmeler sonucunda elde edilen veriler rekreasyon potansiyeli değerlendirme parametrelerine göre puanlanmıştır. Daha sonra puanlar toplanmış ve Çizelge 2'de gösterilen değerler bazında hesaplanarak parkın rekreasyonel potansiyel yüzdesi ortaya çıkarıımıştır. 
Çizelge 1. Gülez yönteminde kullanılan parametreler ve puanlama sistemi (Gülez 1990).

\begin{tabular}{|c|c|c|c|c|}
\hline Ögeler & Öğenin Özellikleri & Puan & Açıklama & \\
\hline \multirow{25}{*}{ 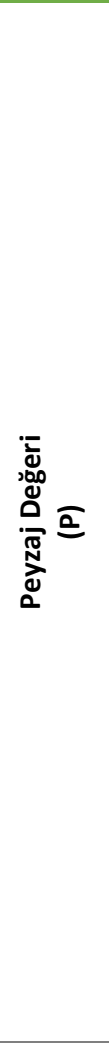 } & \multirow{4}{*}{ Alanın Büyüklüğü } & \multirow{4}{*}{4} & 10 ha.'dan büyük & 4 puan \\
\hline & & & 5-10 ha. & 3 puan \\
\hline & & & 1-5 ha. & 2 puan \\
\hline & & & $0,5-1$ ha. & 1 puan \\
\hline & \multirow{8}{*}{ Bitki Örtüsü } & \multirow{8}{*}{8} & Ağaçlık, çalılık, çayırlık & 7-8 puan \\
\hline & & & Yalnız ağaçlık ve çayırlık & 6-7 puan \\
\hline & & & Çalılık, çayırlık, seyrek ağaçlık & 5-6 puan \\
\hline & & & Çayırlık, seyrek ağaçlık & 4-5 puan \\
\hline & & & Yalnız çalııı ve çayırlık & 3-4 puan \\
\hline & & & Çalılık, seyrek ağaçlık & 3-4 puan \\
\hline & & & Çayırlık, seyrek çalıık & 2-3 puan \\
\hline & & & Yalnız çayırlık & 1-3 puan \\
\hline & \multirow{4}{*}{ Deniz, Göl, Akarsular } & \multirow{4}{*}{8} & Deniz kıyısı & 7-8 puan \\
\hline & & & Göl kıyısı & 6-7 puan \\
\hline & & & Akarsu kıyısı & 4-5 puan \\
\hline & & & Dereler & 1-4 puan \\
\hline & \multirow{5}{*}{ Yüzeysel Durum } & \multirow{5}{*}{5} & Düz alan & 5 puan \\
\hline & & & Hafif dalgalı & 4 puan \\
\hline & & & Az meyilli, yer yer düzlük & 3 puan \\
\hline & & & Az engebeli & 2 puan \\
\hline & & & Orta engebeli & 1 puan \\
\hline & \multirow{3}{*}{ Görsel Kalite } & \multirow{3}{*}{4} & Panaromik görünümler & 3-4 puan \\
\hline & & & Güzel görüş ve vistalar & 2-3 puan \\
\hline & & & Alanın genel görsel estetik değeri & 1-3 puan \\
\hline & Diğer Özellikler & 6 & $\begin{array}{l}\text { Doğal anıt, çağlayan, tarihsel ve kültürel değerler, yaban } \\
\text { hayvanları, kuşlar vs. }\end{array}$ & 1-6 puan \\
\hline \multirow{12}{*}{ 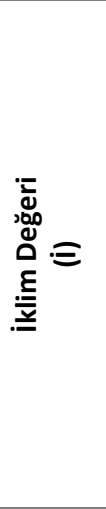 } & \multirow{4}{*}{ Sıcaklık } & \multirow{4}{*}{10} & Yaz ayları(Haz, Tem, Ağ.) ortalaması & \\
\hline & & & ${ }^{\circ} \mathrm{C} 16-17-18-19-20-21-22-23-24-25$ & \\
\hline & & & $34-33-32-31-30-29-28-27-26-25$ & \\
\hline & & & $\begin{array}{llllllllll}\text { P. } 1 & 2 & 3 & 4 & 5 & 6 & 7 & 8 & 9 & 10\end{array}$ & \\
\hline & \multirow[t]{2}{*}{ Yağış } & \multirow[t]{2}{*}{8} & $\begin{array}{l}\text { Yaz ayları(Haz, Tem, Ağ.) toplamı } \\
\text { mm. 50-100-150-200-250-300-350-400 }\end{array}$ & \\
\hline & & & 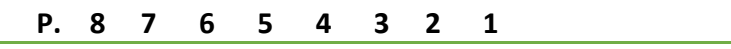 & \\
\hline & \multirow{3}{*}{ Güneşlenme } & \multirow{3}{*}{5} & Yaz ayları bulutluluk ortalaması & \\
\hline & & & Bulutluluk: $2-2,2-4,4-6,6-8,8-9$ & \\
\hline & & & 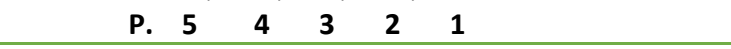 & \\
\hline & \multirow{3}{*}{ Rüzgarlılık } & \multirow{3}{*}{2} & Yaz ayları ortalama rüzgar hızı & 2 puan \\
\hline & & & $1 \mathrm{~m} / \mathrm{sec}^{\prime}$ den daha az & \\
\hline & & & $1-3 \mathrm{~m} / \mathrm{sec}$ & 1 puan \\
\hline \multirow{14}{*}{ 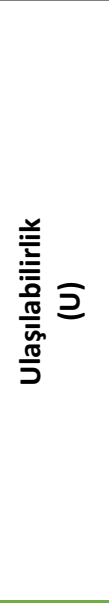 } & & & Akdeniz, Ege, Marmara kıyı bandı & 3-4 puan \\
\hline & Bulunduğu bölgenin turistik önemi & 4 & Karadeniz kıyı bandı & 2-3 puan \\
\hline & & & Önemli karayolu güzergahları, turizmde öncelikli yöreler & 1-3 puan \\
\hline & & & 20 km'ye kadar uzaklık & 4-5 puan \\
\hline & Bulunduğu bölgede en az 100.000 nüfuslu kent & & 50 km’ye kadar uzaklık & 3-4 puan \\
\hline & olması & 5 & 100 km'ye kadar uzaklık & 2-3 puan \\
\hline & & & 200 km'ye kadar uzaklık & 1-2 puan \\
\hline & & & $\begin{array}{l}\text { Yürüyerek } 1 \text { saate kadar ya da taşıtla } \\
0-1 / 2 \text { saat }\end{array}$ & 4 puan \\
\hline & Ulaşılan zaman süresi (yakındaki en az 5000 & 4 & $\begin{array}{l}0-1 / 2 \text { saat } \\
\text { Tasıtla } 1 / 2-1 \text { saat }\end{array}$ & 3 puan \\
\hline & nüfuslu kentten) & & Taşıtla 1-2 saat & 2 puan \\
\hline & & & Taşıtla 2-3 saat & 1 puan \\
\hline & & & Yürüyerek gidebilme ya da her an taşıt bulabilme & 3-4 puan \\
\hline & Ulaşım (taksı ve ozel oto dışında) & 4 & Belirli saatlerde taşıt bulabilme & 1-3 puan \\
\hline & Ulaşımda diğer kolaylıkla & 3 & Denizden, teleferikle ulaşım vs. & 1-3 puan \\
\hline
\end{tabular}


Çizelge 1 (Devamı). Gülez yönteminde kullanılan parametreler ve puanlama sistemi (Gülez 1990).

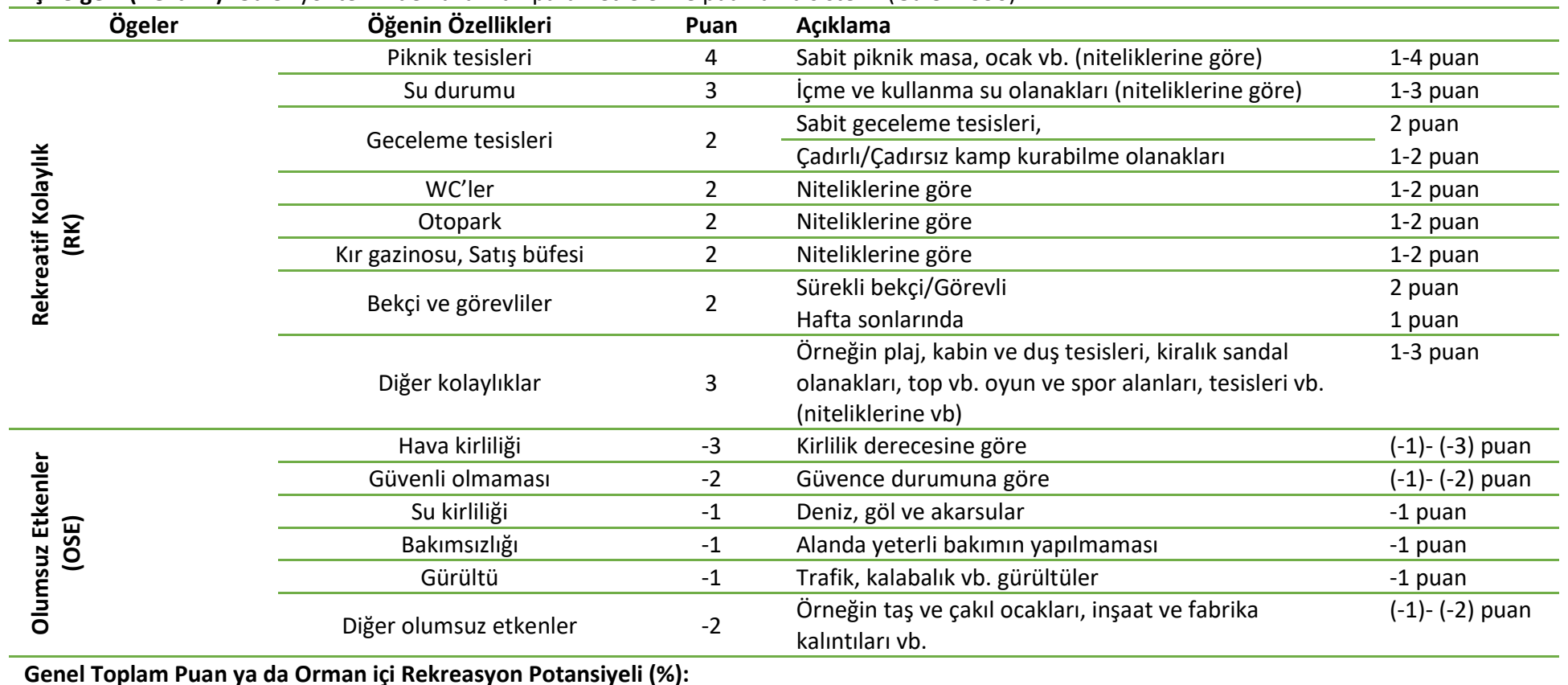

Çizelge 2. Rekreasyonel potansiyel durumunun saptanması (Gülez 1990).

\begin{tabular}{ll}
\hline Rekreasyon Potansiyeli & Değeri \\
\hline Çok Düşük & $<\% 30$ \\
Düşük & $\% 30-\% 45$ aras1 \\
Orta & $\% 46-\% 60$ aras1 \\
Yüksek & $\% 61-\% 75$ aras1 \\
Çok Yüksek & $\% 75<$ \\
\hline
\end{tabular}

\section{BULGULAR}

Rekreasyon potansiyeli değerlendirme çizelgesinde yer alan Peyzaj Değeri (P), iklim Değeri (i), Ulaşılabilirlik (U), Rekreatif Kolaylık (RK), Olumsuz Etkenler (OSE) ögeleri üzerinden alan hakkında yapılan tespitler ve bu tespitlerin değerlendirilmesiyle öge başına verilen puanlar Çizelge 3'de gösterilmiştir.

\section{Peyzaj değeri (P)}

Gülez yönteminde alanın 10 hektardan büyük olduğu durumlarda arazinin büyüklüğü kriteri 4 puan almaktadır. Park, 35,55 hektar büyüklüğünde bir araziye sahiptir (Kavaklımeşe Korusu 2021). Bu nedenle arazinin büyüklüğü ögesi 4 puan olarak değerlendirilmiştir. Çalışma alanı ile ilgili yapılan analizler sonucunda, arazinin düz veya düze yakın bir eğime sahip olduğu belirlenmiştir. Bu nedenle yüzeysel durum ögesine 5 puan verilmiştir. Arazide genel olarak Quercus rubra, Quercus pedunculiflora, Pinus nigra, Rubus canescens, Arbutus unedo türleri bulunmaktadır (Kavaklımeşe Korusu 2021).

Gülez yönteminde bitki örtüsü öğesi alanın genel bitki tipolojisi ile ilgilidir. Gözlemler sonucunda, alan içerisinde ağaç yoğunluğunun fazla olduğu, bunun dışındaki alanların çayırla kaplı olduğu görülmüştür. Bitki örtüsü ögesi ağaçlık ve çayırlık kategorisinde değerlendirilmiş ve alanda yaşlı meşe türleri bulunduğundan 7 puan verilmiştir. Alanda su ögesi bulunmadığından 0 olarak puanlanmıştır.

Arazi değerlendirme formu incelendiğinde, alanın görsel kalite değerinin 3 alt kritere göre puanlandırıldığı görülmektedir. Bu kriterler alanın manzara özellikleri ve estetik değeri ile ilgilidir. Araziye yapılan ziyaretlerde belli noktalardan bakıldı̆ıında, panoramik güzel görünümler ve estetik manzaralar olduğu gözlemlenmiştir. Bu kriterde alınabilecek maksimum puan 4 olduğundan, gözlemlenen manzara görünümleri ve alanın estetik kalitesi değerlendirilerek 3 puan verilmiştir.

'Diğer özellikler' başlı̆ında olan parametreler tek tek alan özelinde değerlendirilmiştir. Söz konusu bu parametreler alana özel değerleri ifade etmektedir. Parkın bir dönem göçmen misafirhanesi olarak kullanılması ve misafirhaneye ait yapıların alanda bulunması tarihi ve kültürel değer olarak değerlendirilmiş, bunun sonucunda diğer özellikler ögesi 2 olarak puanlanmıştır. Tüm puanlar toplandığında Peyzaj Değeri (P) 21 olmaktadır. 
Çizelge 3. Kırklareli ili iklim verileri (MGM 2021).

\begin{tabular}{|c|c|c|c|c|c|c|c|c|c|c|c|c|c|}
\hline & 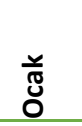 & $\begin{array}{l}\frac{n}{5} \\
\frac{0}{3} \\
0\end{array}$ & 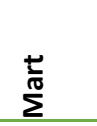 & 点 & 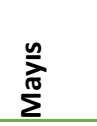 & 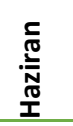 & 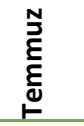 & 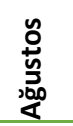 & 㤍 & $\frac{\xi}{\frac{\xi}{4}}$ & $\begin{array}{l}\underline{E} \\
\overline{\tilde{W}} \\
\underline{\tilde{w}}\end{array}$ & $\frac{\text { 兰 }}{\frac{10}{2}}$ & 羔 \\
\hline \multicolumn{14}{|c|}{$(1991-2020)$} \\
\hline Ort. Sıcaklık $\left({ }^{\circ} \mathrm{C}\right)$ & 3.3 & 4.5 & 7.5 & 12.4 & 17.6 & 22.1 & 24.6 & 24.6 & 19.9 & 14.6 & 9.5 & 5.0 & 13.8 \\
\hline Ort. En Yüksek Sıcaklık ( $\left.{ }^{\circ} \mathrm{C}\right)$ & 7.2 & 9.2 & 12.8 & 18.4 & 24.0 & 28.7 & 31.3 & 31.5 & 26.6 & 20.1 & 14.0 & 8.7 & 19.4 \\
\hline Ort. En Düşük Sıcaklık ( $\left.{ }^{\circ} \mathrm{C}\right)$ & 0.3 & 1.0 & 3.4 & 7.3 & 12.0 & 16.1 & 18.4 & 18.6 & 14.5 & 10.3 & 6.0 & 2.1 & 9.2 \\
\hline Ort. Güneş. Süresi (saat) & 2.3 & 2.9 & 4.2 & 5.5 & 7.3 & 7.8 & 8.6 & 8.6 & 6.3 & 4.4 & 3.0 & 2.1 & 5.3 \\
\hline Ort. Yağışlı Gün Sayısı & 9.93 & 8.73 & 10.20 & 10.50 & 10.43 & 9.07 & 5.67 & 3.67 & 5.70 & 8.67 & 9.07 & 11.13 & 102.8 \\
\hline Aylık Top. Yağış Mik. Ort. (mm) & 61.9 & 48.3 & 48.8 & 39.1 & 53.6 & 56.2 & 34.2 & 19.1 & 39.9 & 60.6 & 62.4 & 61.7 & 585.8 \\
\hline
\end{tabular}

\section{iklim değeri (i)}

Gülez yönteminde alanın iklim değerinin ortaya çıkarılması için alanın sıcaklık, yağış, güneşlenme ve rüzgarlılık verileri analiz edilmiş ve Çizelge 1 'de belirtilen puanlara göre değerlendirilmiştir. 1991-2020 yılları arası yaz ayları (Haziran, Temmuz, Ağustos) için oluşturulan ve Meteoroloji Genel Müdürlüğü'nden elde edilen iklim verileri değerlendirilerek (Çizelge 3); sıcaklık öğesine ortalama $23.7{ }^{\circ} \mathrm{C}$ ile 8 puan, yağış ögesine 7 puan, güneşlenme öğesine ortalama $0-2$ bulutluluk oranı ile 5 puan, rüzgarlılık öğesine ise ortalama $1.3 \mathrm{~m} / \mathrm{sec}$ değeri ile 1 puan verilmiştir. Tüm puanlar toplandığında parkın İklim Değeri (i) 21 olmaktadır.

\section{Ulaşılabilirlik (U)}

Bir mekanın ulaşılabilirliği o mekanın kullanım oranı ile doğru orantılıdır. Gülez yönteminde bu durumun ölçülebilmesi için ulaşılabilirlik başlığı altında alt kriterler belirlenmiş ve kriterlere göre bir puanlama sistemi getirilmiştir. Kavaklımeşe Korusu Tabiat Parkı'nın ulaşılabilirlik değerinin belirlenmesi için, başlıkta bulunan alt kriterler çalışma alanı bazında değerlendirilerek puanlandırılmıştır.

Çalışma alanı İstanbul-Kırklareli karayolu üzerinde bulunmaktadır. Bu nedenle bulunduğu bölgenin turistik önemi ögesi, ‘önemli karayolu güzergahları üzerinde bulunmak' kategorisinde değerlendirilerek 2 puan verilmiştir. Kırklareli kentinin 101.451 (TÜiK, 2021) nüfusa sahip olması ve çalışma alanına uzaklığının 10,3 km olması nedeniyle, bulunduğu bölgede 100.000 nüfuslu kent olması ögesine 5 puan verilmiştir. Ulaşılan zaman süresi, Kırklareli merkezi ile çalışma alanı arası gidiş süresi baz alınarak 4 puan olarak belirlenmiştir. Tabiat parkına ulaşım, özel araç dışında belirli saatlerde çalışan otobüs veya minibüslerle sağlanabilmektedir. Bu nedenle ulaşım ögesinin puanı 3 olarak belirlenmiştir. Ulaşımda diğer kolaylıklar başlığında bisikletle ulaşım baz alınmış ve 1 puan olarak değerlendirilmiştir. Tüm puanlar toplandığında parkın Ulaşılabilirlik (U) değeri 15 olmaktadır.

\section{Rekreatif kolaylık (RK)}

Bu başlık altında bulunan kriterler Çizelge 1'de belirtildiği üzere niteliklerine göre değerlendirilmektedir. Her değerlendirmenin bir puan karşılığı vardır. Kavaklımeşe Korusu Tabiat Parkı'na düzenlenen ziyaretler boyunca Çizelge 1 'de belirtilen kriterler gözlemlenmiş ve bunun sonucunda puanlamalar oluşturulmuştur.

Arazi gözlemleri esnasında park içerisinde donatı olarak; sabit piknik tesisleri, oturma bankları, çeşmeler, 1 adet çocuk parkı, çöp kutuları, yönlendirme levhaları, 2 adet tuvalet, eski bir su deposu, harabe yapılar, 1 adet kullanılmayan paintball tesisi tespit edilmiştir. Kavaklı Belediyesi tarafından alana kazandırılan yeni piknik tesislerinin dışındaki bank, oturma alanları ve diğer tesislerin nitelik bakımından kötü durumda olduğu gözlemlenmiştir. Bu nedenle piknik tesisleri ögesi 2 puan almıştır. İçme ve su kullanma olanakları kapsamında alanda bulunan çeşmeler nitelik bakımından değerlendirilerek 1 puan verilmiştir.

Gülez yönteminde tuvaletler kriteri 1 ya da 2 puan alabilmektedir. Bu kriterde tuvaletler nitelik açısından değerlendirilmekte ve puanlandırılmaktadır. Çalışma alanında yapılan gözlemlerde tuvaletler nitelik olarak orta seviyede değerlendirilmiş ve bu nedenle wc'ler ögesi, 1 puan almıştır. Alanda geceleme tesisleri otopark ve satış birimleri bulunmadığından bu başlıklar 0 olarak puanlanmıştır.

Tabiat parkı, hafta içi ve hafta sonu saat 08.30-23.30 saatleri arasında hizmet vermekte ve bu saatler arasında 2 adet vardiyalı çalışan görevli bulunmaktadır. Bu nedenle bekçi ve görevliler başlığına maksimum puan olan 2 puan verilmiştir. 
Diğer kolaylıklar başlığı altında ise, belirtilen alanların niteliklerine göre değerlendirilip puanlanması gerekmektedir. Belirtilen başlıklardan çocuk oyun alanı kriteri alanda bulunmaktadır. Bu alan niteliğine göre değerlendirildiğinde bazı oyuncakların kötü durumda olması ve alanın kirliliği nedenlerinden dolayı minimum puan olan 1 puan olarak hesaplanmıştır.

Tüm puanlar toplandığında parkın Rekreatif Kolaylık (RK) değeri 7 olmaktadır (Şekil 2).

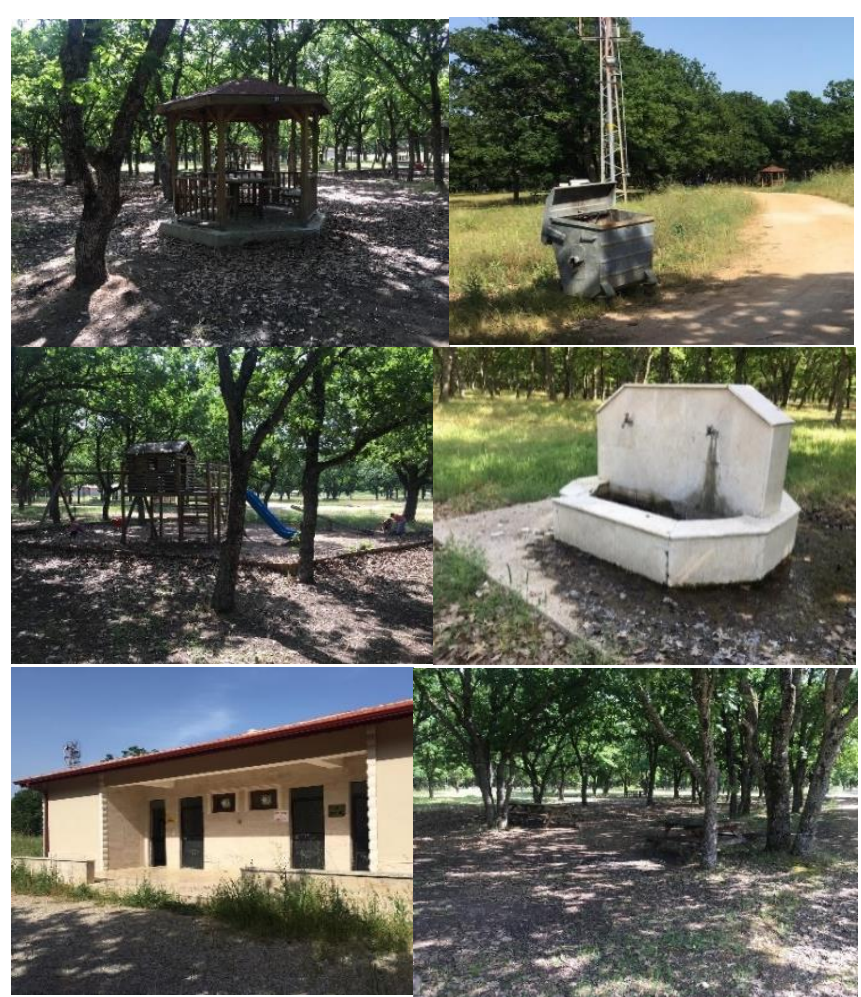

Şekil 2. Çalışma alanındaki rekreatif kolaylık öğeleri.

\section{Olumsuz etkenler (OSE)}

Elde edilen bilgiler ve yapılan gözlemler sonucunda, alanda gürültü ve hava kirliliği; su öğesi bulunmadığı için ise su kirliliği olmadığı sonucuna varılmış ve bu ögeler 0 olarak puanlanmıştır. Bazı zamanlarda bekçi ve görevlilerin alanda olmadığı gözlemlendiğinden güvenli olmaması ögesine -2 puan verilmiştir. Park içerisinde bazı alanlarda çöpler bulunmaktadır. Tuvaletlerin ise orta derecede bakımlı olduğu gözlemlenmiştir. Piknik tesislerinin ve alanda bulunan yapısal ögelerin bir kısmının kullanılamayacak halde veya harabe niteliğinde olduğu tespit edilmiştir. Bu nedenle bakımsızlık öğesi -1 puan olarak değerlendirilmiştir.

Çalışma alanı bir dönem göçmen misafirhanesi olarak kullanılmıştır. Arazi gezisi esnasında kullanılmayan ve harabe durumda misafirhane yapıları tespit edilmiş, yıkılmış olan yapıların ise kalıntılarına rastlanmıştır. Bu kalıntılar; yapılardan kalma demirler, beton ayaklar vb. gibi yapısal unsurlardır ve tehlike arz etmektedirler. $\mathrm{Bu}$ nedenle diğer olumsuz etkenler ögesi -2 olarak puanlanmıştır. Tüm puanlar toplandığında parkın Olumsuz Etkenler (OSE) değeri -5 olmaktadır (Şekil 3).

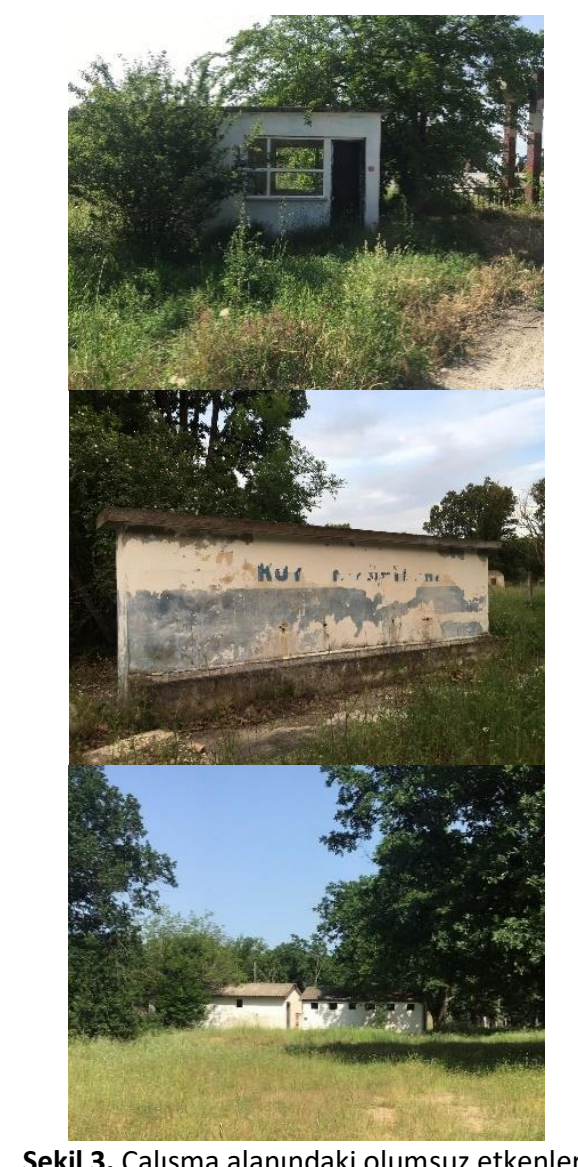

\section{Alanın rekreasyonel potansiyeli}

Tüm ögelerin puanları toplandığında parkın rekreasyonel potansiyel değeri \%59 olarak belirlenmiştir. Bu değer Çizelge 4'de yer alan potansiyel yüzdeleri ve potansiyel derecelerine göre değerlendirildiğinde; Kavaklımeşe Korusu Tabiat Parkı'nın orta derecede rekreasyon potansiyeline sahip olduğu sonucuna varılmıştır.

\section{TARTIŞMA VE SONUÇ}

Doğal niteliğini koruyabilmiş alanlar, ormanlar ve bozulmamış doğa parçaları, toplumun ve içerisinde yer alan bireylerin psikolojik ve fiziksel yenilenme ihtiyaçlarını karşılayan, açık hava rekreasyon faaliyetlerine yer veren doğal kaynakların başında gelmektedir (Demirel 1997). Bu nedenle kent insanı yakın çevrede bulunan ormanlar, tabiat parkları, kent ormanları gibi rekreasyonel intiyaca cevap veren doğal veya yarı doğal alanları tercih 
etmektedir. Kavaklımeşe Korusu Tabiat Parkı da yakın konumundan dolayı Kırklareli kenti ve Kavaklı beldesinde ikamet eden insanlar tarafından sıklıkla tercih edilen, bazı zamanlarda Edirne ve Lüleburgaz gibi yakın kentlerden de ziyaretçi çekebilen rekreasyon alanlarından biridir. Ziyaret sıklığına rağmen, çalışma sonucunda orta derecede rekreasyon potansiyeline sahip olduğu belirlenen parkın, ziyaretçilere konforlu, güvenli ve zengin bir deneyim sunamamakta olduğu sonucuna ulaşılmıştır. Kavaklımeşe Korusu Tabiat Parkı konumu, sahip olduğu doğal ve kültürel kaynak değerlerinden dolayı büyük bir potansiyel barındırmaktadır. Ancak bakımsızlık, güvenlik sorunu, fonksiyon alanlarının ve tesislerin niteliksiz ve yetersizliği, plansız düzenlemeler gibi olumsuz etkenler rekreasyonun kalitesini düşürerek alanın mevcut potansiyelini perdelemektedir. Parkın kaliteli bir hizmet sunabilmesi açısından rekreatif unsurların artırılması ve olumsuz etkenlerin azaltılması gerekmektedir. Bu doğrultuda alanla ilgili öneriler getirilmeye çalışlacaktır.

Çizelge 4. Çalışma alanına ait rekreasyon potansiyeli

\begin{tabular}{|c|c|c|c|}
\hline Ögeler & Ögenin Özellikleri & Maksimum Puan & Aldığı Puan \\
\hline \multirow{6}{*}{ 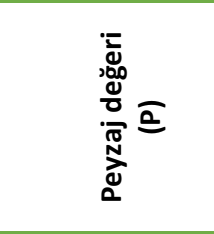 } & Alanın büyüklüğü & 4 & 4 \\
\hline & Bitki örtüsü & 8 & 7 \\
\hline & Su kaynağı varlığı & 8 & 0 \\
\hline & Yüzeysel durum & 5 & 5 \\
\hline & Görsel kalite & 4 & 3 \\
\hline & Diğer özellikler & 6 & 2 \\
\hline Toplam: & & 35 & 21 \\
\hline \multirow{4}{*}{ 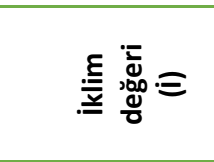 } & Sıcaklık & 10 & 8 \\
\hline & Yağış & 8 & 7 \\
\hline & Güneşlenme & 5 & 5 \\
\hline & Rüzgârlılık & 2 & 1 \\
\hline Toplam: & & 25 & 21 \\
\hline \multirow{7}{*}{ 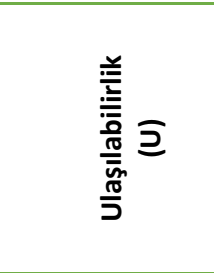 } & Bulunduğu Bölgenin Turistik Önemi & 5 & 2 \\
\hline & Bulunduğu bölgede en az 100.000 nüfuslu kent olması & 4 & 5 \\
\hline & Ulaşılan zaman süresi (yakındaki en az 5.000 nüfuslu kentten) & & \\
\hline & Ulaşım (taksi ve özel oto dışında) & 5 & 4 \\
\hline & Ulaşımda diğer kolaylıklar & & \\
\hline & & 3 & 3 \\
\hline & & 3 & 1 \\
\hline Toplam: & & 20 & 15 \\
\hline \multirow{8}{*}{ 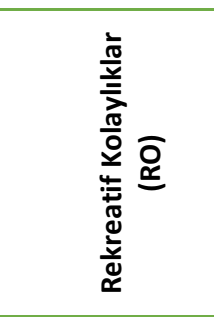 } & Piknik tesisleri & 4 & 2 \\
\hline & Su durumu & 3 & 1 \\
\hline & Geceleme tesisleri & 2 & 0 \\
\hline & WC'ler & 2 & 1 \\
\hline & Otopark & 2 & 0 \\
\hline & Satış birimlerinin olması (büfe vb) & 2 & 0 \\
\hline & Bekçi ve görevliler & 2 & 2 \\
\hline & Diğer kolaylıklar & 3 & 1 \\
\hline Toplam: & & 20 & 7 \\
\hline \multirow{6}{*}{ 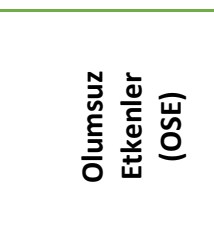 } & Hava kirliliği & -3 & 0 \\
\hline & Güvenli olmaması & -2 & -2 \\
\hline & Su kirliliği & -1 & 0 \\
\hline & Bakımsızlık & -1 & -1 \\
\hline & Gürültü & -1 & 0 \\
\hline & Diğer olumsuz etkenler & -2 & -2 \\
\hline Toplam: & & -10 & -5 \\
\hline GENEL TOPLAM: & & 100 & 59 \\
\hline
\end{tabular}

Doğal kaynak değerleri korunarak devamlılı̆ı̆ın sağlanması için koruma-kullanım dengesi gözetilerek arazi kullanım kararları doğrultusunda alanın tekrar planlanması; detaylı analizlerle alanın uygun şekilde tekrar tasarlanması gerekmektedir. Yeni rekreasyon alanları, etkinlik alanları, otopark, kamp tesisleri, spor alanları, macera parkurları vb. alanlar oluşturulmalı, alan içi sirkülasyon sistemi yeniden düzenlenmelidir. Ayrıca 
son zamanlarda alanda kros ve yağlı güreş müsabakaları yapılmakta olduğundan bu etkinlikler için özel alanlar tasarlanmalıdır. Bir alanın Rekreasyonel kalitesini, rekreasyon alanının doğru planlanması, donatı elamanlarının tasarımı ve kullanımları, en az doğal ve kültürel değerler kadar etkilemektedir (Aksu 2015). Bu nedenle doğru malzeme, renk, doku, ölçü ile alanla bütünleşebilecek özgün donatı elemanları (piknik tesisleri, oturma elemanları, stantlar, çöp konteynerleri, aydınlatma elemanları, güvenlik kulübesi, yönlendirici tabelalar vs.) tasarlanmalıdır.

Alanın genel görüntüsü bakımsızdır. Giriş kapısından itibaren görülen harabe yapılar ve niteliksiz tesisler, kullanılamayacak durumda olan oturma bankları, bakımsız bitkiler parkın kalitesiz ve bakımsız algılanmasına neden olmaktadır. Bu nedenle söz konusu yapılar restore edilmeli veya alandan uzaklaştırılmalı, bitkilere gereken bakım uygulanmalıdır. Alanda bulunan yapı, tesis ve alanlar nitelik ve nicelik yönünden iyileştirilmelidir. Ayrıca alanın büyüklüğüne oranla görevli sayısının az oluşu ve özellikle akşam kullanımları için aydınlatma elemanlarının yetersizliği güvenlik problemi yaratmaktadır.

Aynı yöntemle yapılan Çizelge 5'te gösterilen diğer çalışmalar incelendiğinde ise Kırklareli Kavaklımeşe Korusu Tabiat Parkının rekreasyon potansiyeli açısından alt sıralarda olduğu görülmektedir. Tabiat parkları ile ilgili yapılan çalışmalar arasında ise en düşük ikinci puanı aldığı, peyzaj değeri başığı altında özellikle su varlığı bulunmadığı için puan alamadığı, iklim değerinin diğer tabiat parklarıyla yaklaşık değerlerde olduğu, erişilebilirlik konusunda imkanlarının daha yüksek olduğu, rekreatif kolaylıklar anlamında ise eksiklerinin fazla olduğu ve olumsuz etmenlerinin de bulunduğu görülmektedir.

Kavaklımeşe Korusu Tabiat Parkı'nın bir dönem göçmen misafirhanesi olarak kullanılması parkın kültürel kaynak değeri kapsamında değerlendirilebilir. Park içerisinde atıl halde bulunan o döneme ait eski yapılar restore edilerek ve göç kavramı özelinde etkinlikler alanları oluşturularak parka bir hafıza mekanı statüsü getirilebilir ve sembol mekan niteliğinde yeni bir kimlik kazandırabilir.

Çizelge 5. Gülez yöntemi ile rekreasyon potansiyeli belirlenen diğer çalışmalar.

\begin{tabular}{|c|c|c|c|c|c|c|}
\hline Gülez Yöntemi ile Rekreasyon Potansiyeli Belirlenen Alanlar & $\begin{array}{l}\text { Peyzaj } \\
\text { Değeri }\end{array}$ & $\begin{array}{l}\text { İklim } \\
\text { Değeri }\end{array}$ & Ulaşılabilirlik & $\begin{array}{l}\text { Rekreatif } \\
\text { Kolaylıklar }\end{array}$ & $\begin{array}{l}\text { Olumsuz } \\
\text { Etkenler }\end{array}$ & Toplam \\
\hline Artvin Kafkasör Kent Ormanı (Yılmaz vd. 2009) & 26.19 & 15.25 & 14.99 & 17.31 & -6.34 & 66.9 \\
\hline Tekirdağ Kıyı Şeridi (Korkut ve Şimşek 2009) & 26 & 22 & 19 & 6 & -8 & 65 \\
\hline Limni Gölü Tabiat Parkı (Birici vd. 2016) & 25 & 12 & 9 & 13 & 0 & 59 \\
\hline Bursa İli Gölyazı Köyü (Çelik vd. 2016) & 35 & 15 & 18 & 7 & -3 & 72 \\
\hline Bursa İli Mustafakemalpaşa İlçesi (Çelik ve Çalışkan 2017) & 38 & 16 & 19 & 10 & -4 & 79 \\
\hline Istranca (Yıldız) Ormanları (Sü Eröz ve Aslan 2017) & 34 & 17 & 16 & 13 & -3 & 77 \\
\hline Ordu Kurul Kalesi (Atabeyoğlu vd. 2017) & 21 & 15 & 14 & 7 & -2 & 55 \\
\hline Deriner Baraj Gölü ve Yakın Çevresi (Surat 2017) & 26 & 23 & 11 & 10 & -7 & 63 \\
\hline Limni Gölü Tabiat Parkı (Yeşil ve Hacıoğlu 2018) & 25 & 17 & 10 & 11 & -1 & 62 \\
\hline Samsun Kıyı Şeridi (Gül ve Yılmaz 2019) & 25 & 19 & 19 & 19 & -4 & 78 \\
\hline Kapıçam Tabiat Parkı (Özçalık ve Kumru 2019) & 29 & 22 & 13 & 16 & - & 80 \\
\hline Gürün (Sivas) İlçesi Gökpınar Gölü (Bozkurt 2019) & 27 & 11 & 8 & 20 & -1 & 65 \\
\hline Limni Gölü Tabiat Parkı (Pekünlü vd. 2020) & 32 & 18 & 10 & 17 & - & 77 \\
\hline Limni Gölü Tabiat Parkı (Tozkoparan vd. 2020) & 26 & 14 & 9 & 3 & -1 & 51 \\
\hline Niğde Atatürk Kent Ormanı (Çetinkale Demirkan ve Sandal Erzurumlu 2020) & 20.5 & 14 & 13.77 & 13.69 & -6.16 & 55.8 \\
\hline Çankırı Kadınçayırı Milli Parkı (Tülek 2021) & & & & & & 66.3 \\
\hline Turgut Özal Tabiat Parkı (Çavuş ve Aker 2021) & 22 & 23 & 13 & 15 & -3 & 70 \\
\hline Kırklareli Kavaklımeşe Korusu Tabiat Parkı & 21 & 21 & 15 & 7 & -5 & 59 \\
\hline
\end{tabular}

\section{KAYNAKLAR}

Aksu Ö (2015) Korunan Doğal Rekreasyon Alanlarında Donatı Elemanlarının Tasarımları: Altındere Vadisi Milli Parkı Örneği. Kastamonu Üniversitesi Orman Fakültesi Dergisi 15(2): 267 - 278

Akten S, Gül A (2014) Korunan doğal alanlarda ziyaretçilerin olası etki düzeyleri önlem ve standartların belirlenmesi (Gölcük Tabiat Parkı örneği). SDÜ Orman Fakültesi Dergisi 15: 130-139

Aran S (1967) Tabiatı Koruma ve Peyzaj Güzelliklerinin Muhafazası Bakımından Milli Parklarımızın Önemi, Milli Parklar ve Tabiatın Korunması Cemiyeti, Yayın No: 10, Ankara
Atabeyoğlu Ö, Beyli KN, Argan A (2017) Recreational Potential of Kurul Castel Archaeological Treasure of Black Sea Region, Ordu City. İnönü Üniversitesi Sanat ve Tasarım Dergisi 7(16): 126-140

Birici S, Zaman M, Bulut I (2016) Limni Gölü Tabiat Parkının (Gümüşhane) Rekreasyon Potansiyeli. Journal of International Social Research 9(46): 285-294

Bozkurt S (2019) Gürün (Sivas) İlçesi Gökpınar Gölü ve Çevresinin Rekreasyon Potansiyelinin Belirlenmesi. Türkiye Peyzaj Araştırmaları Dergisi 2 (1): 29-39

Clark RN, Stankey GH (1979). The Recreation Opportunity Spectrum: A Framework for Planning, Management, and Research. Department

329 /F. Aslan, O. Ateş, N. Büyükbayraktar, E. Kabataş / AÇÜ Orman Fak Derg 22(2):321-330 (2021) 
of Agriculture, Forest Service, Pacific Northwest Forest and Range Experiment Station, USA, 32p.

Clawson M (1959) Methods of Measuring the Demand for and Value of Outdoor Recreation. Resources for the Future, Inc., Washington, D.C., 36p.

Çakır G, Çakır A (2012) iğneada Longoz Ormanları Ve Çevresinin Rekreasyonel Faaliyetler Açısından Değerlendirilmesi. KSÜ Doğa Bilimleri Dergisi Özel Sayı: 281-286

Çavuş A, Aker P (2021) Turgut Özal Tabiat Parkı'nın Rekreasyon Potansiyelinin Belirlenmesi. Turizm Akademik Dergisi, 8 (1), 193212

Çelik A, Çalışkan H (2017) Bursa Illi Mustafakemalpaşa Illçesinin Peyzaj Değerleri ve Rekreasyon Potansiyelinin Belirlenmesi Üzerine Araştırma. Uluslararası Turizm, Ekonomi ve İşletme Bilimleri Dergisi 1 (2): 13-22

Çelik A, Polat Üzümcü T, Çetin i (2016) Bursa İli Gölyazı Köyü’nün Açık Hava Rekreasyon Potansiyeli. International Journal of Social and Economic Sciences 6(2): 32-40

Çetinkale Demirkan G, Sandal Erzurumlu G (2020) According to method of Gülez determination of recreational potential of Niğde Atatürk City Forest. Journal of Social and Humanities Sciences Research 7(52): 986-995

Çidam FB (2007) Diyarbakır Kent Dokusunun Turizm ve Rekreasyon Kaynaklarının Peyzaj Mimarlığı Açısından Değerlendirilmesi. Ankara Üniversitesi Fen Bilimleri Enstitüsü Yüksek Lisans Tezi, Ankara, $221 \mathrm{~s}$

Daiute, RJ (1966) Methods for Determination of Demand for Outdoor Recreation. Land Economics, 42(3), 327-338.

Demirel Ö (1997) Çoruh Havzası (Yusufeli Kesimi) Doğal Kaynak Değerlerinin Rekreasyon ve Turizm Potansiyeli Açısından Değerlendirilmesi Üzerine Bir Araştırma. Karadeniz Teknik Üniversitesi Fen Bilimleri Enstitüsü Doktora Tezi, Trabzon, $303 \mathrm{~s}$

Gül A (2005) Korunan doğal alanların planlama sorunları ve ekolojik yönetim planı önerisi. Çevre ve Orman Bakanlığı 1. Çevre ve Ormancılık Şurası Tebliğleri, Cilt:4, Ankara, s. 1421-1429

Gül A, Örücü ÖK, Karaca Ö (2005) Korunan alanlarda rekreasyon uygunluk analizi ile potansiyel alanların belirlenmesi (Gölcük Tabiat Parkı örneği). Korunan Doğal Alanlar Sempozyumu Sözlü Bildiriler Kitabı, Isparta, s. 423-432

Gül S, Yılmaz A (2019) Samsun Şehri Deniz Kıyı Şeridinin Rekreasyon Potansiyelinin Belirlenmesine Yönelik Bir Yöntem Uygulaması. Coğrafi Bilimler Dergisi 17(2): 318-344

Gülez S (1990) Ormaniçi rekreasyon potansiyelinin saptanması için geliştirilen bir değerlendirme yöntemi. İstanbul Üniversitesi Orman Fakültesi Dergisi 40(2): 132-147

Kavaklımeşe Korusu (2021) http://kavaklimesekorusu.tabiat.gov.tr/ Erişim Tarihi: 19.05.2021

Kılıçaslan Ç (2008) Ortaca Kenti Rekreasyon Alanlarının Mevcut Durumu ve Muğla Üniversitesi Ortaca Meslek Yüksekokulu Öğrencilerinin Rekreasyon Alanlarına Yönelik Beklentileri. Düzce Üniversitesi Ormancılık Dergisi 4(1-2): 3-16

Kırklareli il Kültür ve Turizm Müdürlüğü https://kirklareli.ktb.gov.tr/ Erişim Tarihi: 25.09.2021

(2021)

Kiemstedt H (1967) Zur Bevverlung der Landschaft für die Erholung. Evaluation zur Landespflege. Sonderheft; 1, Verlag Eugen Ulmer, Stuttgart

Knetsch, JL (1963) Outdoor Recreation Demands and Benefits. Land Economics, 39(4), 387-396.

Korkut D, Şimşek D (2009) Kıyı Şeridi Rekreasyon Potansiyelinin Belirlenmesinde Bir Yöntem Uygulaması: Tekirdağ Merkez illçe Örneği. Tekirdağ Ziraat Fakültesi Dergisi 6(3): 315-327

Kraus RG (1977) Recreation Today: Program, Planning And Leadership (Second Edition), California: Goodyear Publishing Company, USA
Lier HN (1972) Research on Some Technical Aspects of Outdoor Recreation, as Part of Multipurpose Rural Reconstructions in the Netherlands. Netherlands Journal Of Agricultural Science 3: 154179

Masozera MK, Alavalapati JRR (2004) Forest dependency and its implications for protected areas management: a case study from the Nyungwe Forest Reserve, Rwanda. Scandinavian Journal of Forest Research 19(004): 85-92

MGM (2021) https://www.mgm.gov.tr/veridegerlendirme/il-ve-ilceleristatistik.aspx?m= KIRKLARELI. Erişim Tarihi: 19.05.2021

MTA (2021) http://yerbilimleri.mta.gov.tr/anasayfa.aspx Erişim Tarihi: 25.09.2021

Nowaczek A (2003) Planning for selective use and ecologically compatible forms of outdoor recreation: One means of core area revitalization in the City of Waterloo, Ontario. University Of Waterloo Master Thesis, USA

OGM (2021) Tarım ve Orman Bakanlığı Orman Genel Müdürlüğü Kırklareli Orman İşletme Müdürlüğü

Özçalık M, Kumru S (2019) Kapıçam Tabiat Parkı'nın Gülez Yöntemine Göre Rekreasyon Potansiyelinin Belirlenmesi. Turkish Journal of Forest Science 3(2): 129-141

Öztürk S (2005) Kastamonu-Bartın Küre Dağları Milli Parkının Rekreasyonel Kaynak Değerlerinin İrdelenmesi. Süleyman Demirel Üniversitesi Orman Fakültesi Dergisi 6(2): 138-148

Pekünlü S, Sezen I, Özer S (2020) Limni Gölü Tabiat Parkının Rekreasyon Potansiyelinin Gülez Yöntemine Göre Değerlendirilmesi. In: Alptekin MY (Ed.) Sosyal Bilimlerde 2020 Gündemi Türkiye ve Doğu Karadeniz. Serander Yayınevi, Türkiye, 253 - 264

Putz FE, Blate GM, Redford, KH, Fimbel R, Robinson J (2001) Tropical forest management and conservation of biodiversity: an overview. Conservation Biology, 15(1): 7-20

Serarslan MZ, Bakır B (1988) Turizm Pazarlamasında Sporun Yeri Ve Türkiye Açısından Değerlemesi. Pazarlama Dünyası 2(9): 28- 30

Surat H (2017) Gülez Yöntemine Göre Deriner Baraj Gölü ve Yakın Çevresi Rekreasyonel Potansiyelinin Değerlendirilmesi ve Alan Kullanım Önerilerinin Geliştirilmesi. KSÜ Doğa Bil. Dergisi 20(3): 247-257

Sü Eröz S, Aslan E (2017) Istranca Yıldız Ormanlarının Rekreasyon Potansiyelinin Gülez Metodu ile Değerlendirilmesi. Kesit Akademi Dergisi (9): 83-107

TUiK (2021) http://www.tuik.gov.tr. Erişim Tarihi: 19.05.2021

Tozkoparan U, Atayeter Y, Yayla O (2020) Altınpınar (Limni) Gölü (Torul/Gümüşhane) ve Yakın Çevresinin Rekreasyon Potansiyelinin Belirlenmesine Yönelik Bir Yöntem Uygulaması. Doğu Coğrafya Dergisi 25(44): 61-84

Tülek B (2021) Determination of Recreation Potential with Using Gülez Method in Çankırı Kadınçayırı Natural Park Example. ISPEC Tarım Bilimleri Dergisi 5(1): 227-234

Uzun S (2005) Kırsal ve Kentsel Alanlardaki Parklarda Kullanıcı Memnuniyeti: Gölcük Orman içi Dinlenme Alanı ve İnönü Parkı Örneği. Abant İzzet Baysal Üniversitesi Fen Bilimleri Enstitüsü Peyzaj Mimarlığı ABD Yüksek Lisans Tezi, Bolu, $104 \mathrm{~s}$

Yeşil P, Hacıoğlu V (2018) Limni Gölü Tabiat Parkı Peyzaj Değerlerinin Rekreasyonel Açıdan Değerlendirilmesi. Türk Tarım - Gıda Bilim ve Teknoloji Dergisi, 6(6): 680-688

Yılmaz S (2004) Serçeme Vadisinin Rekreasyonel Kullanım Potansiyelinin Belirlenmesi. Ekoloji, 13(51): 1-6

Yılmaz H, Karaşah B, Erdoğan Yüksel E (2009) Gülez Yöntemine Göre Kafkasör Kent Ormanının Rekreasyonel Potansiyelinin Değerlendirilmesi. Artvin Çoruh Üniversitesi Orman Fakültesi Dergisi 10(1): 53-61 